\title{
Characterisation of M2e Antigenicity using anti-M2 Monoclonal Antibody and anti-M2e Polyclonal Antibodies
}

\author{
Sumarningsih ${ }^{1}$, Tarigan $\mathrm{S}^{1}$, Hemmatzadeh $\mathrm{F}^{2}$, Ignjatovic $\mathrm{J}^{3}$ \\ ${ }^{I}$ Balai Besar Penelitian Veteriner, Jl RE Martadinata 30 Bogor 16114 \\ ${ }^{2}$ School of Animal and Veterinary Science, The University of Adelaide, SA, Australia \\ ${ }^{3}$ Faculty of Veterinary Science, University of Melbourne, Victoria 3010, Australia \\ E-mail: drh.sumarningsih@gmail.com
}

(received: 01-07-2019; revised: 20-08-2019; accepted: 24-09-2019)

\begin{abstract}
ABSTRAK
Sumarningsih, Tarigan S, Hemmatzadeh F, Ignjatovic J. 2019. Antigenik karakterisasi pada protein M2e menggunakan antibodi monoklonal anti-M2 dan antibodi poliklonal anti-M2e. JITV 24(3): 122-134. DOI: http://dx.doi.org.10.14334/jitv.v24i3.1987

Protein Matrik 2 ektodomain (M2e) memiliki sifat lestari dan dianggap sebagai antigen potensial untuk mendeteksi infeksi virus influenza A pada unggas yang divaksinasi (DIVA test). Namun studi yang mempelajari antigenisitas M2 dan respon imun pada manusia atau hewan masih sangat terbatas. Pada studi ini sifat antigenik dari masing-masing tujuh belas M2e peptida dan enam belas protein rekombinan M2e (rM2e) yang memiliki variasi asam amino (aa) pada posisi 10, 11, 12, 13, 14, 16, 18 dan 20 dibandingkan dengan metode western blot (WB) dan enzyme-linked immunosorbent assay (ELISA) menggunakan antibodi monoklonal (mAb) 14C2 dari tikus, dan anti-M2e poliklonal antibody (pAb) yang berasal dari ayam dan kelinci. MAb 14C2 memiliki kekuatan pembeda terbaik dan aa posisi ke-11 merupakan imunodominan paling penting yang mempengaruhi ikatan mAb14C2 hingga tingkat yang terbesar. Perubahan pada posisi 14, 16 dan 18 juga mempengaruhi pengikatan mAb14C2, dan perubahan ini terdeteksi pada semua metode (WB atau ELISA) dan antigen yang digunakan (M2e peptida atau protein rM2e). Untuk anti-M2e pAb dari ayam dan kelinci, aa imunodominan ditemukan pada posisi 10 dan perubahan pada posisi 11 tidak mempengaruhi reaksi antibodi. Pengikatan pAb kelinci juga dipengaruhi oleh perubahan pada aa posisi 14 dan 16 , hal ini mengkonfirmasi kontribusi posisi tersebut terhadap antigenisitas M2e. Posisi 10 adalah satu-satunya posisi yang penting untuk pengikatan pAb ayam terhadap M2e. Secara keseluruhan penelitian ini menunjukkan antigenik M2e terletak di antara residu 10 18 dan perubahan aa pada posisi 10,11,12,14, 16 dan 18, dapat mempengaruhi ikatan antibodi di dalam protein M2e.
\end{abstract}

Kata kunci: Virus Influenza A, epitop M2e, antigenisitas

\section{ABSTRACT}

Sumarningsih, Tarigan S, Hemmatzadeh F, Ignjatovic J. 2019. Characterisation of M2e antigenicity using anti-M2 monoclonal antibody and anti-M2e polyclonal antibodies. JITV 24(3): 122-134. DOI: http://dx.doi.org.10.14334/jitv.v24.i3.1987

Ectodomain matrix 2 protein (M2e) is a potential antigen for detection of influenza-A-virus infection among vaccinated birds (DIVA test). However, the antigenicity and immune response induced by M2e in either humans or animals are poorly understood. Seventeen M2e peptides and sixteen recombinant M2e (rM2e) proteins with amino acid (aa) changes introduced at position 10,11,12, 13 14, 16, 18 and 20 were compared by western blot (WB) and enzyme-linked immunosorbent assay (ELISA) using mouse anti-M2 monoclonal antibody (mAb) 14C2, and chicken- or rabbit-polyclonal antibodies (pAb). The mAb $14 \mathrm{C} 2$ had the best discriminating power and aa position 11 was the important immunodominant for mAb14C2, that affected binding to a greatest degree. Changes in the adjacent position 14, 16 and 18 also influenced the binding, and it detected regardless of the method (WB or ELISA), or the antigen used (M2e peptide or rM2e). For chicken pAb and rabbit pAb, the immunodominant aa was position 10 and the antibody reaction was not affected by aa change at 11 . The binding of rabbit pAb was also affected by changes at 14 and 16, which confirm the contribution of these positions to the M2e antigenicity. Position 10 was the only important position for the binding of chicken pAb to M2e. Overall, the study showed that the M2e antigenic sites are located between residues $10-18$ and that aa changes at position 10,11,12,14, 16 and 18 may all affect the antibody binding within the M2e protein.

Key Words: Influenza A Virus, M2e epitope, antigenicity

\section{INTRODUCTION}

Highly pathogenic avian influenza subtype H5N1, has continued to be a significant concern for more than a decade globally, and especially in several South East
Asia countries where the virus has become endemic in commercial poultry. As fatalities in humans, which have been directly linked to contacts with infected poultry continue to occur, measure that would reduce virus load in the environment, such as vaccination, are 
now practiced in several countries. In some countries additional measures are considered such as using the differentiation of infected from vaccinated animals (DIVA) test for use in surveillance of vaccinated flocks in order to estimate the extent of $\mathrm{H} 5 \mathrm{~N} 1$ challenge in vaccinated flocks.

Ectodomain matrix 2 (M2e) protein is a 24 amino acid long protein located in the Matrix 2 (M2) protein $\mathrm{N}$ terminal. It is abundantly express on the cell surface infected by Influenza A virus (IAV), but very few are found in the virion of AIV (Lamb et al. 1985). Previous study, using mouse mAb $14 \mathrm{C} 2$ reported that M2e was the most important part for antigenicity of $\mathrm{M} 2$ protein as mAb 14C2 could not recognise the M2 lacking the ectodomain (M2e) protein (Zebedee \& Lamb 1988). $\mathrm{M} 2 \mathrm{e}$ protein is considered to be a potential antigen for DIVA test and high specificity of enzyme-linked immunosorbent assay (ELISA) using synthetic M2epeptide or recombinant $\mathrm{M} 2 \mathrm{e}$ protein has been reported by several studies (Lambrecht et al. 2007; Hemmatzadeh et al. 2013; Tarigan et al. 2015). Although the M2e based DIVA test has been evaluated for possible use in commercial poultry (Lambrecht et al. 2007; Hemmatzadeh et al. 2013; Kim et al. 2010, Tarigan et al. 2015), very little is known about the antigenicity of the $\mathrm{M} 2 \mathrm{e}$ and antibody response it induces in infected poultry. Limited studies, however, have been carried on M2e antigenicity and immunogenicity and these studies were mostly focused on the M2e responses in humans, mice, pigs or ferrets (Schotsaert et al. 2009). Those studies concluded that M2e was a poor immunogen and induced antibodies only in a fraction of infected individuals, and antibody titres were low and of short duration (Feng et al. 2006); (Kitikoon et al. 2008); (Bianchi et al. 2001). In addition, antigenic variations in the M2e protein have only been studied using monoclonal antibodies (Zharikova et al. 2005; Zebedee \& Lamb 1988).

In chickens, only limited studies have dealt with the immune responses to the M2e protein. An M2e-peptide based ELISA was used as a DIVA test to identify chickens and ducks challenged with HPAI viruses H5N1 and H7N7 (Hemmatzadeh et al. 2013: Lambrecht et al. 2007; Marché et al. 2010). Twentyfour and eighteen amino acid long M2e peptides were recognised in ELISA by immune chicken sera indicating that on the M2e peptide at least some, if not all, antigenic domains are correctly presented. Although antibodies to M2e were detectable, they were not consistently detected and were absent in chicks infected with LPAI isolated from water birds. In another study it was also shown that the M2e-peptide based ELISA was able to detect infection with H9N2 strain in vaccinated commercial poultry (Kim et al. 2010). In these studies the synthetic M2e peptide and recombinant $\mathrm{M} 2 \mathrm{e}$ (rM2e) coupled to maltose bonding protein (MBP) were used to assess the suitability of M2e as a DIVA reagent (Lambrecht et al. 2007; Hemmatzadeh et al. 2013), and in another study also as a vaccine candidate (Mozdzanowska et al. 2003). Overall, these studies have indicated that synthetic M2e peptide is suitable for DIVA, and rM2e may both be useful for antigenic mapping of the M2e.

To date, limited report is available regarding M2e antigenicity in chickens or recognition of M2e by sera from various AIV infections (Lambrecht et al. 2007; Marché et al. 2010; Kim et al. 2010). For successful implementation of a DIVA test, it is critical to understand if M2e can be used as a universal detecting agent. Therefore, this study aimed to characterise the antigenic epitopes on M2e and identify critical mutations that influence binding of antisera to the M2e antigen. For this purpose, M2e-MBP recombinant proteins were generated as well as synthetic peptides carrying different mutations in the M2e protein, and used to analyse the M2e antigenic determinants. Two different immunological assays, WB and ELISA, were employed to achieve a comprehensive evaluation of M2e antigenicity using polyclonal antibodies (pAb) generated in chicken and rabbit against the $\mathrm{M} 2 \mathrm{eCO}$ peptide. Monoclonal antibody (mAb) $14 \mathrm{C} 2$ was also purchased and used for antigenic characterisation and for comparison with the anti-M2e peptide $\mathrm{pAb}$.

\section{MATERIALS AND METHODS}

\section{Production of recombinant M2e proteins (rM2e)}

The synthetic M2e gene (M2eC0) was used to generate fifteen $\mathrm{M} 2 \mathrm{e}$ mutant genes $(\mathrm{M} 2 \mathrm{eC} 1$ to $\mathrm{M} 2 \mathrm{eC} 15)$ by introducing various mutations at specific sites (Sumarningsih, 2011). These fifteen M2e genes were cloned into pMAL-P4x expression vector and transformed into E. coli BL21 DE3 cell (BioLine Pty Ltd, Alexandria, NSW) to express recombinant M2eMBP proteins, referred to as $\mathrm{rM} 2 \mathrm{e}(\mathrm{C} 1$ to $\mathrm{C} 15)$. After cold osmotic shocked, the expressed proteins were purified with amylose resin beads (New England Biolabs, UK), and analysed by polyacrylamide gel electrophoresis in sodium dodecyl sulfate (SDS-PAGE) for the size and purity.

\section{Synthetic M2e peptide}

All M2e peptides ( $\mathrm{C} 1$ to $\mathrm{C} 18$ ) were synthetized by GenScript (Piscataway, New Jersey, USA) corresponding to the sequences of M2e mutants (Table 1) with purity varied from $79 \%$ to $94 \%$. The $\mathrm{M} 2 \mathrm{eC} 15$ peptide was not synthesized because it had homolog sequence to that of $\mathrm{M} 2 \mathrm{eC} 14$. The $\mathrm{M} 2 \mathrm{eC} 17$ peptide was also not included in this study because the synthesis was unsuccessful even after three different attempts by 
GenScript. In initial study, $\mathrm{M} 2 \mathrm{eC} 0$ peptide was purchased from Peptide 2.0 (Chantilly, VA, USA). All these seventeen peptides ( $\mathrm{C} 0$ to $\mathrm{C} 18)$ were dissolved in sterile $\mathrm{ddH}_{2} \mathrm{O}(1 \mathrm{mg} / \mathrm{ml})$ and diluted in 1:1 with sterile glycerol and stored at $-20^{\circ} \mathrm{C}$.

\section{Anti-M2 monoclonal antibody $14 \mathrm{C} 2$ and anti-M2e polyclonal antibodies}

Mouse monoclonal antibody (mAb) 14C2 was purchased from Abcam, (Sapphire BioScience Pty Ltd, NSW) as ascetic fluid. The mAb $14 \mathrm{C} 2$ was generated against the M2 protein of Influenza A Virus A/WSN/33 following live inoculation. In this study, mAb $14 \mathrm{C} 2$ was optimised by ELISA titration using $\mathrm{M} 2 \mathrm{eC} 3$, $\mathrm{M} 2 \mathrm{eC} 4$ and $\mathrm{M} 2 \mathrm{eC} 11$ peptides to determine the optimal dilution for mAb 14C2 in WB and ELISA.

Anti-M2e polyclonal antibodies (pAb) were produced in chicken and rabbit immunized using $1 \mathrm{mg}$ of $\mathrm{M} 2 \mathrm{eC} 0$ peptide in complete Freund's adjuvant, followed by $2 \mathrm{mg}, 4 \mathrm{mg}$ and $8 \mathrm{mg}$ of M2eC0 peptide with incomplete Freund's adjuvant (as a second, third and fourth immunisation, in 3 weeks intervals). Chicken and rabbit were bled prior to each immunisation and the $\mathrm{pAb}$ were tested in $\mathrm{M} 2 \mathrm{eC} 0$ peptide ELISA to determine the titres. The sera were harvested after the third immunisation when the optimum titres of $\mathrm{pAb}$ were found.

\section{Western blot (WB)}

All sixteen rM2e proteins ( $\mathrm{C} 0$ to $\mathrm{C} 15)$ were subjected by polyacrylamide gel electrophoresis in sodium dodecyl sulfate (SDS-PAGE) and then transferred to polyvinylidene difluoride (PVDF) membrane. The membrane was washed two times using PBS-T $(0.5 \%$ Tween in PBS) and incubated in blocking buffer (5\% skim milk in PBS) for 1.5 hours. All incubations for WB were performed at room temperature. After washing two times, the membrane was incubated with diluted primary antibody for 1 hour, washed five times, and incubated with diluted HRP-conjugated antibody for 1 hour. Different antibody dilution was used for each WB. First WB used dilution at 1/5000 for $\mathrm{mAb} 14 \mathrm{C} 2$ and 1/2000 for HRPrabbit anti mouse IgG. Second $\mathrm{WB}$ used dilution at $1 / 2000$ for rabbit $\mathrm{pAb}$ and $1 / 2000$ for HRP-goat anti rabbit IgG. Third WB used dilution at $1 / 1000$ for chicken $\mathrm{pAb}$ and 1/4000 for HRP-rabbit anti chicken
IgG. The antigen-antibody interaction was visualized using Amersham enhanced chemiluminescent (ECL) western blotting detection reagents (GE Healthcare Australia Pty Ltd, Rydalmere, NSW). The membrane was exposed to blue rite autorad film (Astral Pty Ltd, Gymea, NSW) and scanned to measure the band mass by Kodak molecular imaging software.

Value of $100 \%$ was given for the band intensity of homologous M2e sequence between antibody and antigen use in each WB. The band intensity for antibody binding to other M2e proteins was then compared to the homologous $\mathrm{M} 2 \mathrm{e}$ reaction and expressed as a percentage of binding. Decrease in band intensity of a minimum of 25 to $30 \%$ was indicative the reduction in antibody binding.

\section{Enzyme-linked immunosorbent assay (ELISA)}

All the procedures for ELISA were performed at room temperature. Both ELISA used antigen concentration at $0.6 \mathrm{ng} /$ well for rM2e proteins and M2e peptides, which dissolved in carbonate-bicarbonate buffer (pH 9.6) and coated into each well of microtitre plate (NUNC Maxisorb). After coating for overnight, the plate was washed once with PBS-Tween $0.05 \%$ (PBS-T). Then $150 \mu \mathrm{l} /$ well of blocking buffer $(5 \%$ Newborn Calf Serum in PBS-T) was added and incubated for 2 hours. After washing two times, $100 \mu 1 /$ well of diluted antibody was added and the plate was incubated for 1 hour. Similar dilution at 1/2000 was used for all antibodies (mAb14C2, chicken pAb and rabbit $\mathrm{pAb}$ ) in rM2e ELISA. But the dilution used in M2e-Peptide ELISA was different, which was $1 / 4000$ for mAb14C2 and rabbit pAb; and 1/2000 for chicken pAb. After incubated with antibody, the microplate was washed five times, followed by incubation with $100 \mu \mathrm{l} /$ well of diluted HRP-antibody for 1 hour. The dilution at 1/2000 was used for HRP-rabbit anti mouse $\mathrm{IgG}$ and HRP-goat anti rabbit $\mathrm{IgG}$, and at $1 / 4000$ dilution for HRP-rabbit anti chicken IgG. After washing five times, $100 \mu \mathrm{l} /$ well of $3,3^{\prime}$, ,5,5'tetramethylbenzidine (TMB) susbtrate (Sigma Aldrich Pty Ltd, Castle Hill, NSW) was added and incubated for 15 minutes. The reaction was stopped by adding $25 \mu 1 /$ well of $2 \mathrm{M} \mathrm{H} 2 \mathrm{SO} 4$. The binding of antibody to antigen was determined based on the optical density (OD) using microplate reader at a wavelength of 450nm (OD450). 
Table 1. Amino acid sequences for the parent and mutant genes of M2e

\begin{tabular}{|c|c|c|c|c|}
\hline \multirow{3}{*}{$\begin{array}{l}\text { M2e } \\
\text { C1 }\end{array}$} & \multirow{2}{*}{$\begin{array}{l}\text { Parent }^{(\mathrm{a})} \\
\text { Mutant }^{(\mathrm{b})}, \text { Peptide }^{(\mathrm{c})}\end{array}$} & \multicolumn{3}{|c|}{ Amino acid sequence } \\
\hline & & & & \\
\hline & $\mathrm{C} 0^{(\mathrm{a})}$ & MSLLTEVETP & TRNEWECKCS & DSSD \\
\hline & $\mathrm{C} 1^{(\mathrm{b}, \mathrm{c})}$ & $\ldots \ldots \ldots$ & $\ldots G \ldots \ldots$ & $\ldots$ \\
\hline \multirow[t]{2}{*}{$\mathrm{C} 2$} & $\mathrm{C} 1^{\text {(a) }}$ & MSLLTEVETP & TRNGWECKCS & DSSD \\
\hline & $\mathrm{C} 2^{(\mathrm{b}, \mathrm{c})}$ & $\ldots \ldots \ldots L$ & $\ldots \ldots \ldots$ & $\ldots$ \\
\hline \multirow[t]{2}{*}{$\mathrm{C} 3$} & $\mathrm{C} 1^{\text {(a) }}$ & MSLLTEVETP & TRNGWECKCS & DSSD \\
\hline & $\mathrm{C} 3^{(\mathrm{b}, \mathrm{c})}$ & $\ldots \ldots \ldots$ & I...... & $\ldots$ \\
\hline \multirow[t]{2}{*}{$\mathrm{C} 4$} & $\mathrm{C} 3^{\text {(a) }}$ & MSLLTEVETP & IRNGWECKCS & DSSD \\
\hline & $\mathrm{C} 4^{(\mathrm{b}, \mathrm{c})}$ & $\ldots \ldots \ldots$ & $\ldots K \ldots \ldots$ & $\ldots$ \\
\hline \multirow[t]{2}{*}{$\mathrm{C} 5$} & $\mathrm{C} 0^{\text {(a) }}$ & MSLLTEVETP & TRNEWECKCS & DSSD \\
\hline & $\mathrm{C} 5^{(\mathrm{b}, \mathrm{c})}$ & $\ldots \ldots \ldots$ & $\ldots \ldots R \ldots$ & $\ldots$ \\
\hline \multirow[t]{2}{*}{ C6 } & $\mathrm{C} 5^{(\mathrm{a})}$ & MSLLTEVETP & TRNEWECRCS & DSSD \\
\hline & $\mathrm{C} 6^{(\mathrm{b}, \mathrm{c})}$ & $\ldots \ldots \ldots$ & ...G.G... & $\ldots$ \\
\hline \multirow[t]{2}{*}{$\mathrm{C} 7$} & C6 $6^{(\mathrm{a})}$ & MSLLTEVETP & TRNGWGCRCS & DSSD \\
\hline & $\mathrm{C} 7^{(\mathrm{b}, \mathrm{c})}$ & $\ldots \ldots \ldots \mathrm{L}$ & $\ldots \ldots \ldots$ & $\cdots$ \\
\hline \multirow[t]{2}{*}{$\mathrm{C} 8$} & C6 ${ }^{\text {(a) }}$ & MSLLTEVETP & TRNGWGCRCS & DSSD \\
\hline & $\mathrm{C} 8^{(\mathrm{b}, \mathrm{c})}$ & $\ldots \ldots \ldots \mathrm{H}$ & $\ldots \ldots \ldots$ & $\ldots$ \\
\hline \multirow[t]{2}{*}{ C9 } & $\mathrm{C} 7^{\text {(a) }}$ & MSLLTEVETL & TRNGWGCRCS & DSSD \\
\hline & $\mathrm{C} 9^{(\mathrm{b}, \mathrm{c})}$ & $\ldots \ldots \ldots$ &.$K \ldots \ldots$ & $\ldots$ \\
\hline \multirow[t]{2}{*}{$\mathrm{C} 10$} & $\mathrm{C} 5^{(a)}$ & MSLLTEVETP & TRNEWECRCS & DSSD \\
\hline & $\mathrm{C} 10^{(\mathrm{b}, \mathrm{c})}$ & $\ldots \ldots \ldots$ & I $\ldots \ldots$ & $\ldots$ \\
\hline \multirow[t]{2}{*}{$\mathrm{C} 11$} & $\mathrm{C} 10^{(\mathrm{a})}$ & MSLLTEVETP & IRNEWECRCS & DSSD \\
\hline & $\mathrm{C} 11^{(\mathrm{b}, \mathrm{c})}$ & $\ldots \ldots \ldots$ & $\ldots$..... & $\ldots$ \\
\hline \multirow[t]{2}{*}{$\mathrm{C} 12$} & $\mathrm{C} 1^{(\mathrm{a})}$ & MSLLTEVETP & TRNGWECKCS & DSSD \\
\hline & $\mathrm{C} 12^{(\mathrm{b}, \mathrm{c})}$ & $\ldots \ldots \ldots$ & $\ldots s \ldots \ldots$ & $\ldots$ \\
\hline \multirow[t]{2}{*}{ C13 } & $\mathrm{C} 3^{(\mathrm{a})}$ & MSLLTEVETP & IRNGWECKCS & DSSD \\
\hline & $\mathrm{C} 13^{(\mathrm{b}, \mathrm{c})}$ & $\ldots \ldots \ldots$ & $\ldots \ldots R \ldots$ & $\ldots$ \\
\hline \multirow[t]{2}{*}{$\mathrm{C} 14^{*}$} & $\mathrm{C} 5^{\text {(a) }}$ & MSLLTEVETP & TRNEWECRCS & DSSD \\
\hline & $\mathrm{C} 14^{(\mathrm{b}, \mathrm{c})}$ & $\ldots \ldots \ldots$ & $\ldots G \ldots \ldots$ & $\ldots$ \\
\hline \multirow[t]{2}{*}{$\mathrm{C} 15^{*}$} & $\mathrm{C} 2^{\text {(a) }}$ & MSLLTEVETL & TRNGWECKCS & DSSD \\
\hline & $\mathrm{C} 15^{(\mathrm{b})}$ & $\ldots \ldots \ldots$ & $\ldots \ldots R \ldots$ & $\ldots$ \\
\hline $\mathrm{C} 16$ & $\mathrm{C} 16^{(\mathrm{c})}$ & MSLLTEVETP & TRNEWECKCI & DSSD \\
\hline $\mathrm{C} 18$ & $\mathrm{C} 18^{(\mathrm{c})}$ & MSLLTEVETS & TRNEWECRCS & DSSD \\
\hline
\end{tabular}

${ }^{\text {a) }}$ The M2e parent gene used as a template in mutagenesis

${ }^{b)}$ The M2e mutant gene, product of mutagenesis for rM2e protein expression

c) The M2e sequence for synthetic peptide use in this study

*The sequence of $\mathrm{C} 14$ and $\mathrm{C} 15$ mutant genes were similar but generated from different parent genes 


\section{RESULTS AND DISCUSSION}

The M2e based DIVA test has been considered as the test of choice for use in surveillance of vaccinated flocks in Indonesia in order to estimate the extent of H5N1 challenge in vaccinated flocks and to establish zones that are free from H5N1 (Tarigan et al. 2015; Wibowo et al. 2017). Although the M2e based DIVA test has been evaluated for possible use in commercial poultry, very little is known about the antigenicity of M2e and its specificity to detect infections caused by avian influenza virus (AIV).

The M2e protein has been considered as a highly conserved protein among all influenza A virus (IAV) strains and subtypes. For this reason M2e has been studied as a possible candidate for a universal IAV vaccine (Schotsaert et al. 2009) and also as a potential DIVA diagnostic antigen to detect exposure to different AIV subtypes (Kim et al. 2010; Lambrecht et al. 2007). However, in several studies that have focused on M2e from human IV strains, evolution and mutation at some amino acid positions in the M2e have been reported (Furuse et al. 2009; Ito et al. 1991). Also, data obtained following the emergence and spread of $\mathrm{H} 5 \mathrm{~N} 1$ and additional surveillance in wild birds have further indicated that the M2e protein may also be under the similar selection pressure as are the HA and the NA proteins (Lam et al. 2008). The M2e amino acid variability has also been reported in other studies to occur in the middle part of M2e that potentially could have an affect on its antigenicity (Liu \& Chen 2005; Wang et al. 2009). Ito et al. (1991) reported high M2 variation between positions 10 to 28 , whereas the first nine amino acids (1MSLLTEVET10) were highly conserved. In this study, the amino acid variation in the M2e protein of different strains of $\mathrm{H} 5 \mathrm{~N} 1$ and of other frequently isolated AIV subtypes were determined. The most common mutations were identified for generation of recombinant M2e protein to be used for antigenic mapping of the M2e.

The antigenicity of a protein is strongly associated with the hydrophobicity, 17 M2e amino acid sequence were designed (Table 1) based on the hydrophobicity differences, so that each sequence had between one and five selected mutations in comparison to the rM2eC5 sequence (A/Ck/Indo/BL/03 H5N1 strain). These rM2e proteins had different hydrophobicity values, which indicating the potential of each amino acid position contribute to the M2e antigenicity (result not shown). Peptides analogous to these sequences were synthetized and labeled as $\mathrm{M} 2 \mathrm{eC} 0, \mathrm{M} 2 \mathrm{eC} 1$, etc. Antigenic mapping of M2e was performed by testing the binding of polyclonal and monoclonal antibody to each rM2e proteins in WB and ELISA, and to M2epeptides in ELISA.

\section{Antigenic mapping using anti-M2 monoclonal antibody 14C2 (mAb 14C2)}

Monoclonal antibody $14 \mathrm{C} 2$ was used in this study to compare the M2e antigenicity because it was previously shown to specifically recognise amino acid isoleucine at the position 11 (Zebedee \& Lamb 1988). The $\mathrm{mAb} 14 \mathrm{C} 2$ was generated against the $\mathrm{M} 2$ protein of human influenza virus A/WSN/33/H1N1 strain, and WB result (Figure 1a) showed that $\mathrm{mAb} 14 \mathrm{C} 2$ reacted strongly with $\mathrm{rM} 2 \mathrm{eC} 11$ (homologous reaction), which has similar sequence to M2e of A/WSN/33-H1N1 virus. Introduction of two mutation G16E and N20S into $\mathrm{rM} 2 \mathrm{eC} 10$ was used to generated $\mathrm{rM} 2 \mathrm{eC} 11$, and the WB of rM2eC10 showed that amino acid different in these positions caused a reduction in $\mathrm{mAb} 14 \mathrm{C} 2$ binding to $60 \%$. MAb14C2 also reacted with $\mathrm{rM} 2 \mathrm{eC} 3$, $\mathrm{rM} 2 \mathrm{eC} 4$ and $\mathrm{rM} 2 \mathrm{eC} 13$, that all having isoleucine at the position 11 (11I), but this reaction was lesser in comparison to the homologous reaction, indicating that changes at other positions (E14G, G16E and R18K) could reduce the binding of $\mathrm{mAb} 14 \mathrm{C} 2$. The binding to $\mathrm{rM} 2 \mathrm{eC} 4$ and $\mathrm{rM} 2 \mathrm{eC} 13$ with additional change (E14G) was further reduced to $40 \%$ and $35 \%$, respectively. The reduction to $\mathrm{rM} 2 \mathrm{eC} 3$, which similar to $\mathrm{rM} 2 \mathrm{eC} 13$ (35\%), showed that amino acid change at R18K did not affected the binding of $\mathrm{mAb} 14 \mathrm{C} 2$. Additional mutation (I11T) in rM2eC0, rM2eC1, rM2eC14 and rM2eC15 completely abrogated the mAb $14 \mathrm{C} 2$ binding to these M2e proteins.

In WB of rM2eC5, to which mAb $14 \mathrm{C} 2$ did not bind, when T11I was mutated back generating the $\mathrm{rM} 2 \mathrm{eC} 10$, the binding of $\mathrm{mAb} 14 \mathrm{C} 2$ was restored, but only to $60 \%$ of binding, its indicating clearly different contribution of positions 11, 16, and 20 to $\mathrm{mAb} 14 \mathrm{C} 2$ binding. Although four constructs $\mathrm{rM} 2 \mathrm{eC} 2, \mathrm{rM} 2 \mathrm{eC} 7$, $\mathrm{rM} 2 \mathrm{eC} 8$, and $\mathrm{rM} 2 \mathrm{eC} 9$ had additional $\mathrm{P} 10 \mathrm{~L}$ change, the contribution for this position to M2e antigenicity was not possible to assess because there was no rM2e proteins containing aa differed from $\mathrm{rM} 2 \mathrm{eC} 11$ at position 10 only.

ELISA of mAb $14 \mathrm{C} 2$ using rM2e proteins showed similar result as WB (Figure 1.b.). The binding was only found with $\mathrm{rM} 2 \mathrm{eC} 3, \mathrm{rM} 2 \mathrm{eC} 4, \mathrm{rM} 2 \mathrm{eC} 10$, $\mathrm{rM} 2 \mathrm{eC} 11$ and $\mathrm{rM} 2 \mathrm{eC} 13$, which contain isoleucine at the position 11 (11I). However, the binding to $\mathrm{rM} 2 \mathrm{eC} 3$ and $\mathrm{rM} 2 \mathrm{eC} 4$ was reduced in comparison to $\mathrm{rM} 2 \mathrm{eC} 10$, $\mathrm{rM} 2 \mathrm{eC} 11$ and $\mathrm{rM} 2 \mathrm{eC} 13$, indicating that change at position 18 (R18K) could have affected the antibody binding. MAb $14 \mathrm{C} 2$ also did not react in ELISA with rM2eC0, rM2eC1, rM2eC5, rM2eC6, rM2eC7, rM2eC8, rM2eC9, rM2eC12, rM2eC14 and rM2eC15, and all these rM2e had amino acid change at position 11 (I11T). 


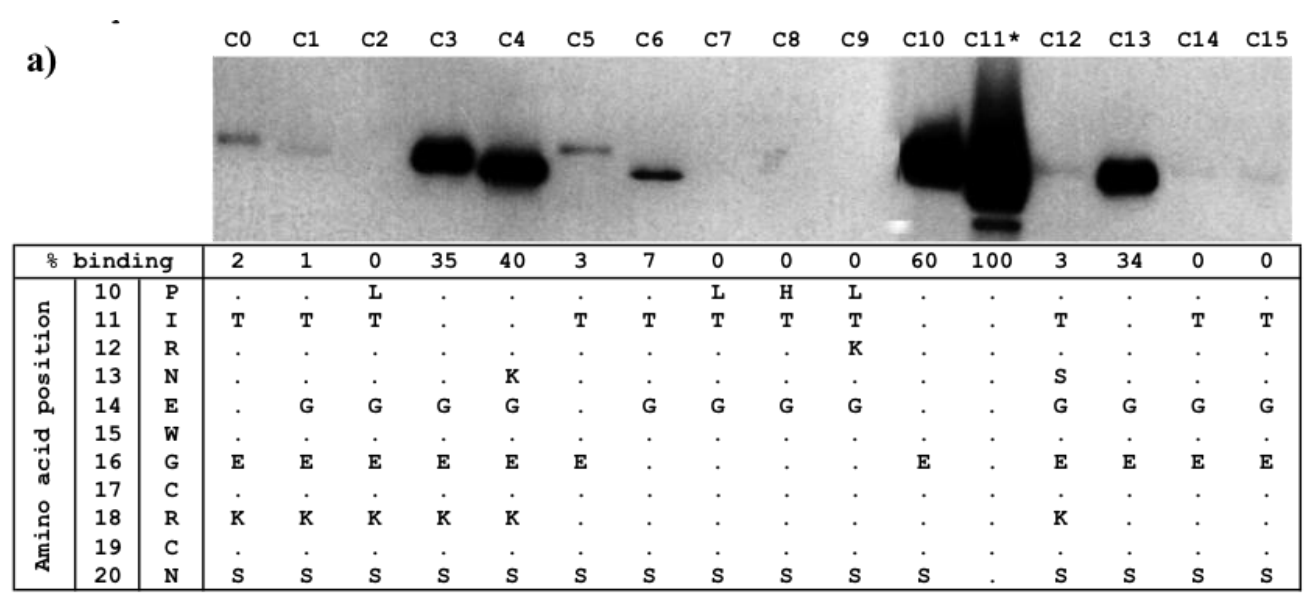

b)

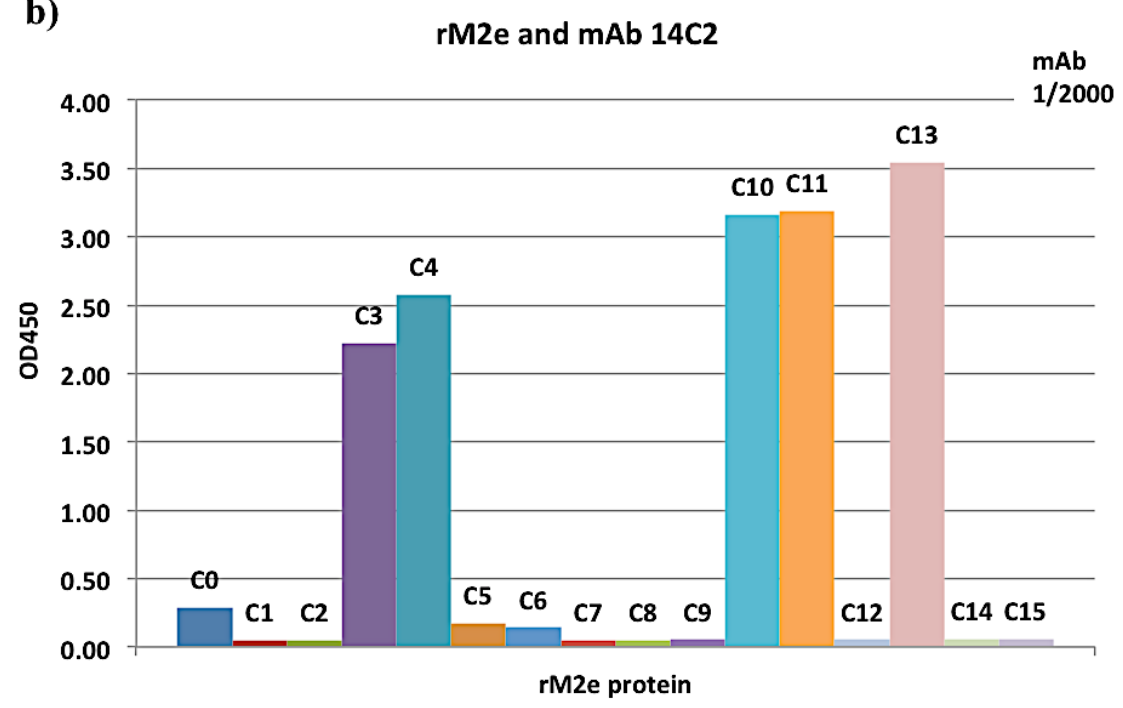

c)

M2e Peptide and mAb $14 C 2$

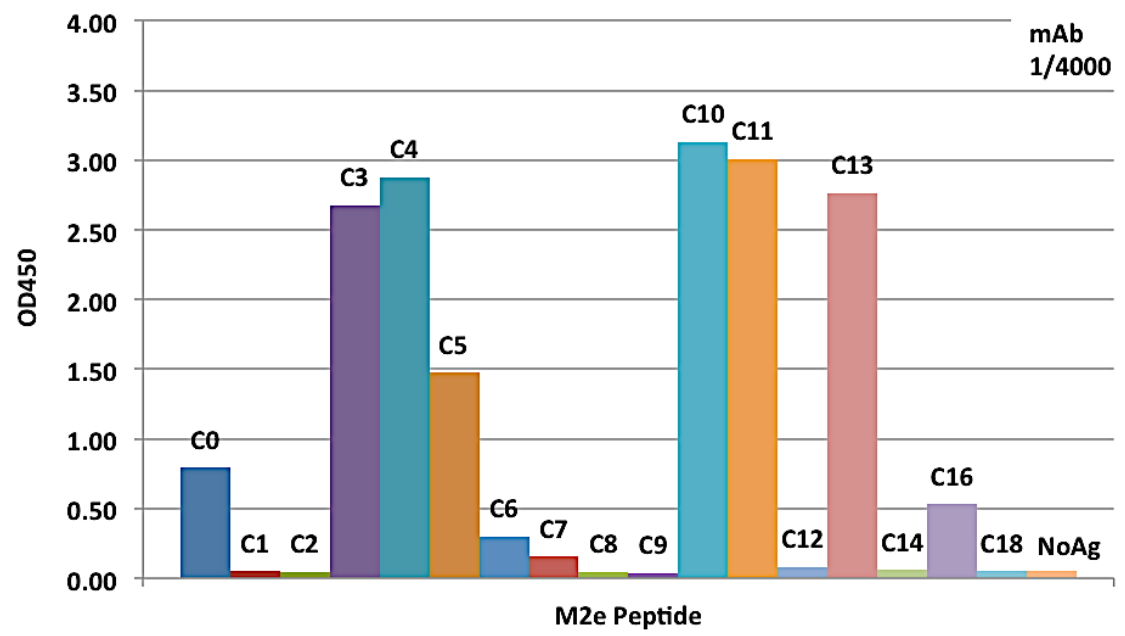

Figure 1. Antibody binding analysis of $\mathrm{mAb} 14 \mathrm{C} 2$ to rM2e proteins in WB (a); mAb $14 \mathrm{C} 2$ to rM2e proteins in ELISA (b); and mAb $14 \mathrm{C} 2$ to M2e peptides in ELISA (c). Amino acid variations between rM2e proteins to rM2eC11 (*) were shown in the table. 


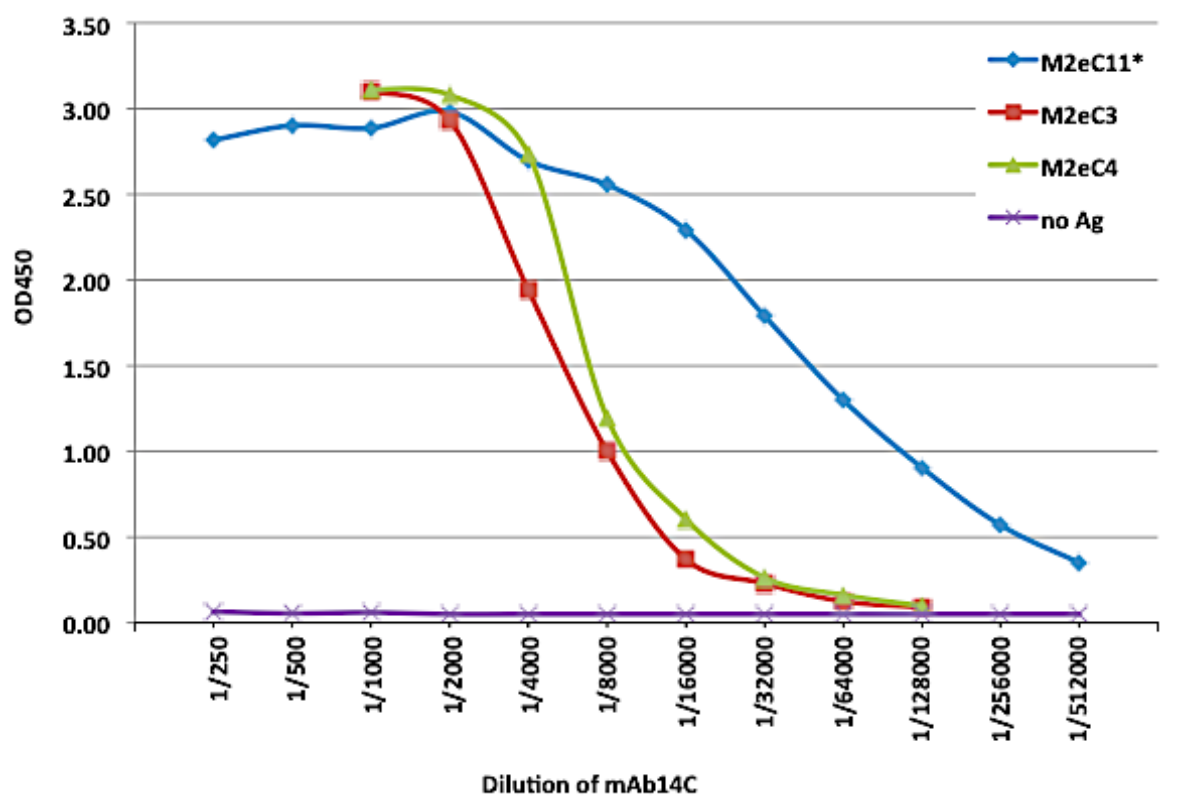

Figure 2. Analysis of mAb $14 \mathrm{C} 2$ titre in ELISA using three different M2e peptides (M2eC3, M2eC4 and M2eC11). M2eC11 peptide has the homologous sequence to human influenza A virus A/WSN/33/H1N1 strain used to generate mAb $14 \mathrm{C} 2$.

Similar finding was obtained in ELISA with M2epeptides (Figure 1.c), mAb 14C2 strongly reacted with all five M2e peptides (M2eC3, M2eC4, M2eC10, $\mathrm{M} 2 \mathrm{eC} 11$ and $\mathrm{M} 2 \mathrm{eC} 13$ ) that had isoleucine at the position 11, and there was no influence of other amino acid changes to this binding. Positive but low reactions of mAb $14 \mathrm{C} 2$ binding was also found with $\mathrm{M} 2 \mathrm{eC} 0$ and $\mathrm{M} 2 \mathrm{eC} 5$ peptides which had threonine at the position 11 (I11T) and had only one common amino acid change in comparisons to the homologous sequence (rM2eC11) at position 20 (N20S). In this study, mAb $14 \mathrm{C} 2$ was titrated on the $\mathrm{M} 2 \mathrm{eC} 11, \mathrm{M} 2 \mathrm{eC} 3$ and $\mathrm{M} 2 \mathrm{eC} 4$ peptides (Figure 2) because the binding of $\mathrm{mAb} 14 \mathrm{C} 2$ to $\mathrm{M} 2 \mathrm{eC} 3$ and $\mathrm{M} 2 \mathrm{eC} 4$ peptide in ELISA differed from the previous result of WB. As shown, there was a difference in binding between these three M2e peptides at the lower concentration of $\mathrm{mAb} 14 \mathrm{C} 2$, indicating that M2eC3 (E14G, G16E, K18R, S20N) and M2eC4 (N13K, E14G, G16E, K18R, S20N) differed antigenically from $\mathrm{M} 2 \mathrm{eC} 11$.

\section{Antigenic mapping using anti-M2e rabbit polyclonal antibody}

To investigate if there was any different M2e antibody response between species of animal immunized, rabbit polyclonal antibody to the $\mathrm{M} 2 \mathrm{eC} 0$ peptide were used in this study to characterise the M2e antigenicity. Strong reactions of rabbit M2e antiserum were detected in WB (Figure 3.a) with $\mathrm{rM} 2 \mathrm{eC} 0$ and rM2eC1 (E14G), rM2eC13 (T11I, E14G, K18R), rM2eC14 (E14G, K18R) and rM2eC15 (E14G, K18R) indicating that changes at the position T11I, E14G, and $\mathrm{K} 18 \mathrm{R}$ did not influence its binding. The results also showed a complete absence of reaction of rabbit $\mathrm{pAb}$ with $\mathrm{M} 2 \mathrm{eC} 2, \mathrm{M} 2 \mathrm{eC} 7, \mathrm{M} 2 \mathrm{eC} 8$ and $\mathrm{M} 2 \mathrm{eC} 9$ that had either P10L or P10H amino acid change. These two changes at position $10(\mathrm{P} 10 \mathrm{~L}$ or $\mathrm{P} 10 \mathrm{H})$ caused the lack of binding equally. It was of interest that amino acid change at position 11 in $\mathrm{rM} 2 \mathrm{eC} 3, \mathrm{rM} 2 \mathrm{eC} 4, \mathrm{rM} 2 \mathrm{eC} 10$, $\mathrm{rM} 2 \mathrm{eC} 11$ and $\mathrm{rM} 2 \mathrm{eC} 13$ did not influence the binding of anti-M2e rabbit pAb, nor did the amino acid changes at the position E14G, G16E and K18R and S20N.

ELISA results using rM2e proteins (Figure 3.b) showed less discriminating value compare to WB. It showed that the highest reaction of rabbit $\mathrm{pAb}$ was with the homologous $\mathrm{rM} 2 \mathrm{eC} 0$ protein, the binding was reduced to $\mathrm{M} 2 \mathrm{eC} 2, \mathrm{M} 2 \mathrm{eC} 7$ and $\mathrm{C} 9$ with changes at position P10L. Result of ELISA M2e-peptide was in agreement with the WB and ELISA rM2e for most peptides (Figure 3.c). Rabbit pAb reacted less with $\mathrm{M} 2 \mathrm{eC} 2, \mathrm{M} 2 \mathrm{eC} 7, \mathrm{M} 2 \mathrm{eC} 8, \mathrm{M} 2 \mathrm{eC} 9$ and $\mathrm{M} 2 \mathrm{eC} 18$, these all peptides has amino acid different to $\mathrm{M} 2 \mathrm{eC} 0$ at position 10 (P10L, P10H and P10S). The differences of antibody binding to M2e were visible only at high dilution (1/4000 concentration) of rabbit pAb indicating the influence of rabbit $\mathrm{pAb}$ concentration for differentiation capacity. 


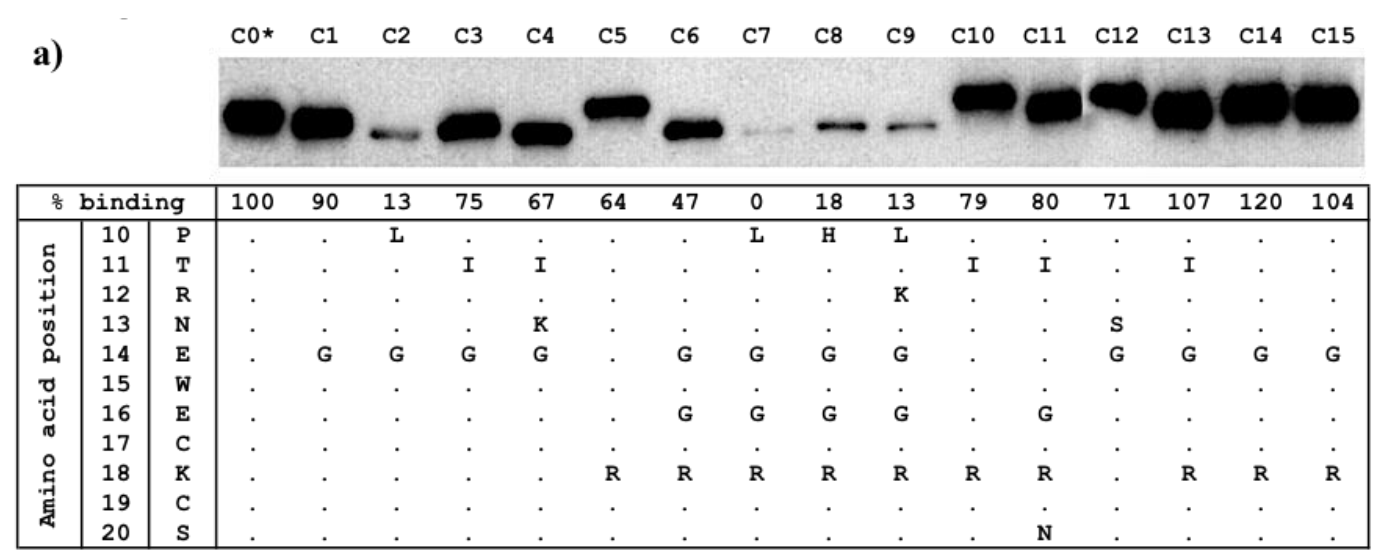

b)

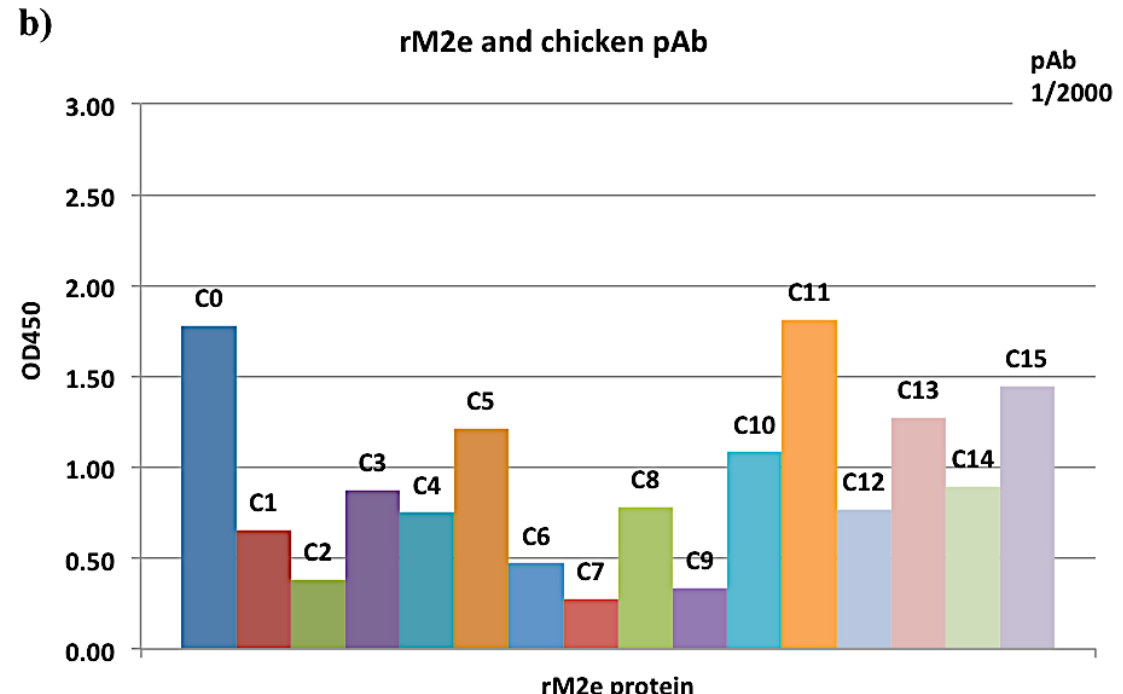

c)

M2e Peptide and rabbit pAb

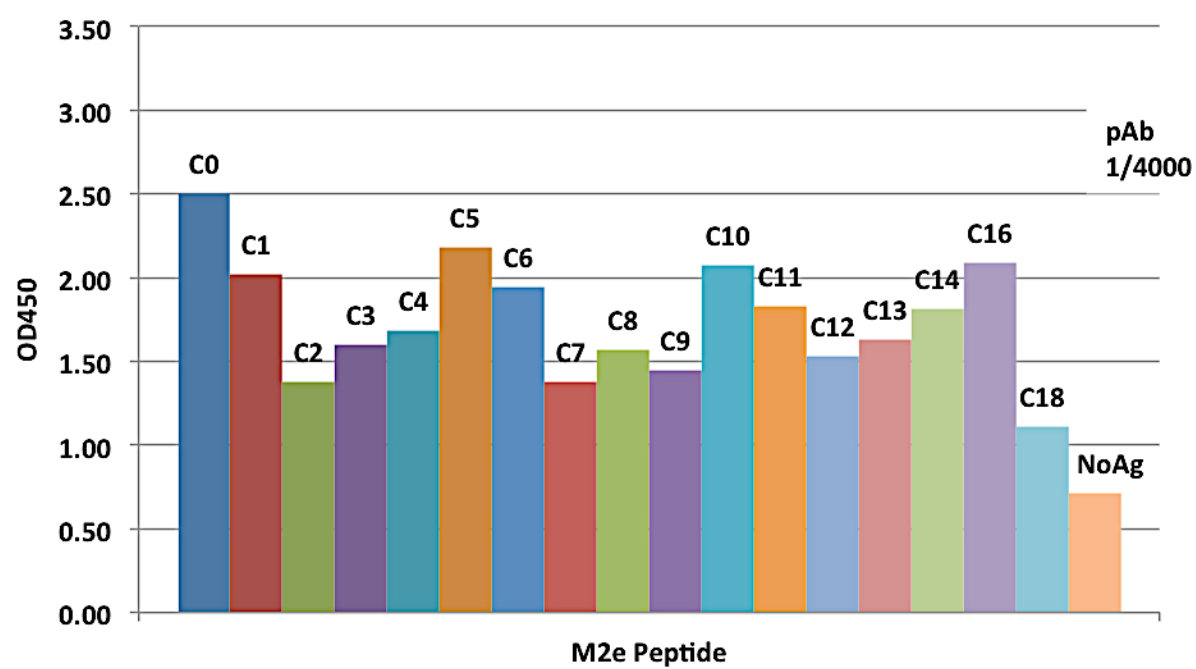

Figure 3. Antibody binding analysis of anti-M2e rabbit pAb to rM2e proteins in WB (a); anti-M2e rabbit pAb to rM2e proteins in ELISA (b); and anti-M2e rabbit pAb to M2e peptides in ELISA (c). Amino acid variations between $\mathrm{rM} 2 \mathrm{e}$ proteins to $\mathrm{rM} 2 \mathrm{eC} 0(*)$ were shown in the table. 
a)

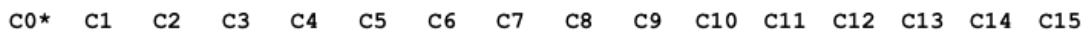

\begin{tabular}{|c|c|c|c|c|c|c|c|c|c|c|c|c|c|c|c|c|c|c|}
\hline \multicolumn{3}{|c|}{8 binding } & 100 & 150 & 83 & 158 & 113 & 155 & 105 & 23 & 75 & 51 & 103 & 160 & 32 & 15 & 46 & 81 \\
\hline \multirow{5}{*}{ 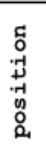 } & 10 & $P$ & $\cdot$ & $\cdot$ & L & . & $\cdot$ & $\cdot$ & $\cdot$ & L & $\mathrm{H}$ & L &. & . &. & . & . & . \\
\hline & 11 & $\mathrm{~T}$ & . & . & . & I & I & . & . & . & . & . & I & I & . & I & . & . \\
\hline & 12 & R & . & . & . & . & . & . & . & . & . & $\mathrm{K}$ & . & . & . & . & . & . \\
\hline & 13 & N & . & . & . & . & K & . & . & . & . & . & . & . & 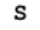 & . & . & . \\
\hline & 14 & E & . & G & G & G & G & . & G & G & G & G & . & . & G & G & G & G \\
\hline \multirow{3}{*}{ త్ర } & 15 & W & . & . & . & . & . & . & . & . & . & . & . & . & . & . & . & . \\
\hline & 16 & E & . & . & . & . & . & . & G & G & G & G & . & G & . & . & . & . \\
\hline & 17 & C & . & . & . & . & . & . & . & . & . & . & . & . & . & . & . & . \\
\hline \multirow{3}{*}{$\begin{array}{l}\stackrel{\circ}{\leftrightarrows} \\
\text { 䍃 }\end{array}$} & 18 & $\mathbf{K}$ & . & . & . & . & . & $\mathbf{R}$ & $\mathbf{R}$ & R & $\mathbf{R}$ & $\mathbf{R}$ & $\mathbf{R}$ & $\mathbf{R}$ & . & $\mathbf{R}$ & $\mathbf{R}$ & $\mathbf{R}$ \\
\hline & 19 & C & . & . & . & . & . & . & . & . & . & . & . & . & . & . & . & . \\
\hline & 20 & $S$ & . & . & . & . & . & . & . & . & . & . & . & $\mathrm{N}$ & . & . & . & . \\
\hline
\end{tabular}

b)

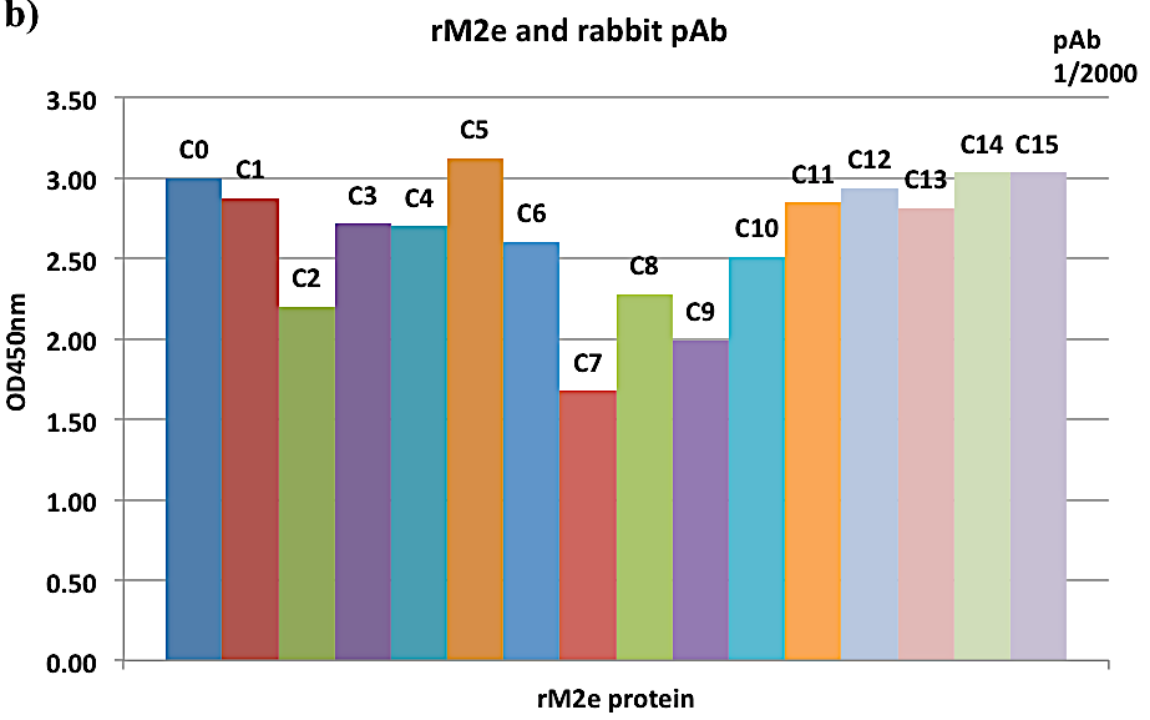

c)

M2e Peptide and chicken pAb

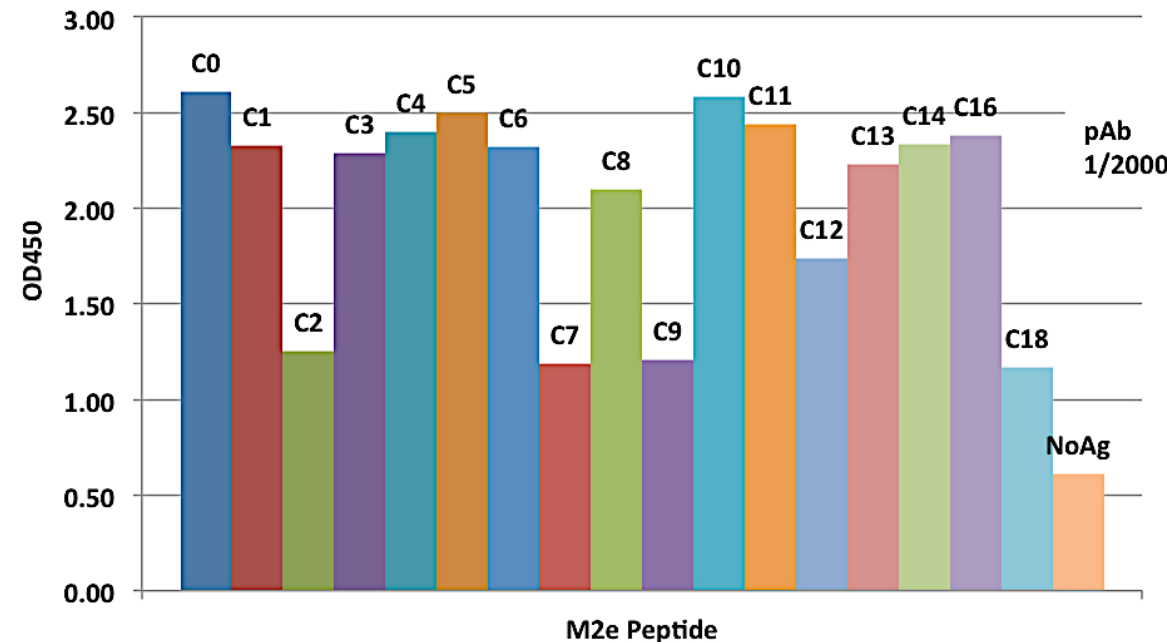

Figure 4. Antibody binding analysis of anti-M2e chicken pAb to rM2e proteins in WB (a); anti-M2e chicken pAb to rM2e proteins in ELISA (b): and anti-M2e chicken pAb to M2e peptides in ELISA (c). Amino acid variations between $\mathrm{rM} 2 \mathrm{e}$ proteins to $\mathrm{rM} 2 \mathrm{eC} 0(*)$ were shown in the table. 


\section{Antigenic mapping using anti-M2e chicken polyclonal antibody}

Anti-M2e chicken polyclonal antibody was also used in this study to analyse the M2e antigenicity. WB result showed chicken pAb (Figure 4.a) was strongly reacted with the homologous $\mathrm{rM} 2 \mathrm{eC} 0$ and other $\mathrm{rM} 2 \mathrm{e}$ proteins, including rM2eC1 (E14G), rM2eC3 (T11I and N13S), rM2eC5 (K18R) rM2eC10 (T11I and K18R) and $\mathrm{rM} 2 \mathrm{eC} 11$ (T11I, E16G, E14G, K18R and S20N). This finding suggested that changes at the position T11I, E14G, E16G, K18R and S20N did not influence the binding of chicken pAb. In contrast, chicken pAb was not reacted or weakly reacted with $\mathrm{rM} 2 \mathrm{eC} 7$ and rM2eC9 that had amino acid change at the position 10 (P10L), rM2eC12 (N13S \& E14G), and rM2eC13 (T11I, E14G and K18R). There was also some reduction of antibody binding to $\mathrm{rM} 2 \mathrm{eC} 2$ (P10L and E14G), rM2eC14 and rM2eC15 (E14G and K18R), which indicate that the change at position 13 (N13S) as well as position 14 and 18 (E14G and K18R) also affected the antibody binding when present simultaneously.

Similar result was obtained from rM2e ELISA, it showed the importance of amino acid changes at position 10 (P10L) and 13 (N13S) (Figure 4.b) for chicken $\mathrm{pAb}$ binding. The binding of chicken $\mathrm{pAb}$ to rM2eC1 (E14G), rM2eC3 (T11I, E14G), rM2eC4 (T11I, R13K, E14G,) rM2eC6 (E14G, E16G, K18R) and $\mathrm{rM} 2 \mathrm{eC} 14$ (E14G, K18R) was reduced significantly $(>50 \%)$, indicating that changes of amino acid T11I, N13S or N13K, E14G, E16G and K18R, had disturbed antigenicity of the M2e, although it has a lesser degree compare to the changes of P10L and N13S.

Analysis using M2e-peptides ELISA (Figure 4.c) was in complete agreement with WB result, it showed significant reduction of chicken $\mathrm{pAb}$ binding to $\mathrm{M} 2 \mathrm{eC} 2, \mathrm{M} 2 \mathrm{eC} 7$ and $\mathrm{M} 2 \mathrm{eC} 12$ peptide. These M2e peptides had a common amino acid change at position 10 (P10L), 13 (N13S) and 14 (E14G). The antibody binding to $\mathrm{M} 2 \mathrm{eC} 18$, which has $\mathrm{P} 10 \mathrm{~S}$ change, was also abrogated. The M2e peptide ELISA indicated the important amino acid for chicken pAb were located at position 10, 11, 14 and 18 .

Table 2. Summary of the important amino acid changes influenced the antibody (mAb 14C2, rabbit pAb, chicken pAb) binding to rM2e in WB, rM2e-ELISA and M2e-peptide ELISA.

\begin{tabular}{|c|c|c|c|}
\hline \multirow{2}{*}{ Antibody } & \multirow{2}{*}{$\mathrm{rM} 2 \mathrm{e}-\mathrm{WB}$} & \multicolumn{2}{|c|}{ ELISA } \\
\hline & & $\mathrm{rM} 2 \mathrm{e}$ & M2e-Peptide \\
\hline \multirow[t]{4}{*}{$\mathrm{mAb} 14 \mathrm{C} 2$} & P10L, H & P10L, H & P10L, H, S \\
\hline & I11T & $\mathrm{I} 11 \mathrm{~T}$ & $\mathrm{I} 11 \mathrm{~T}$ \\
\hline & E14G & E14G & E14G \\
\hline & G16E & G16E & G16E \\
\hline \multirow[t]{5}{*}{ Rabbit pAb } & P10L, H & P10L, H & P10L, H, S \\
\hline & & & $\mathrm{T} 11 \mathrm{I}$ \\
\hline & & & N13K, S \\
\hline & E14G & & E14G \\
\hline & E16G & & E16G \\
\hline \multirow[t]{5}{*}{ Chicken pAb } & P10L & P10L, H & P10L, H \\
\hline & & I11T & I11T \\
\hline & N13S & N13S & E14G \\
\hline & & E14G & \\
\hline & & $\mathrm{K} 18 \mathrm{R}$ & K18R \\
\hline
\end{tabular}


Anti-M2 mAb 142C and anti-M2e pAb (chicken and rabbit) were used in this study to determine the antigenic epitopes on the M2e protein and the result showed that all three antibodies identified the same immunodominant epitopes, although chicken pAb had broader specificity and recognised additional antigenic epitopes on the M2e which were not recognised by rabbit $\mathrm{pAb}$ and $\mathrm{mAb} 14 \mathrm{C} 2$. Overall, all antigenic epitopes identified were located between amino acid position 10 and 18 (Table 2). Single amino acid changes at positions $10,11,13$ and 18 have affected the binding, with amino acid changes at position 14 and 16 possibly acting co-operatively. It was considered that the entire region between amino acid 10 and 18 form a part of a single epitope in which amino acid changes at the position 10, 11 and 13 effect the binding and lead to the lack of recognition by an antibody. Both chicken and rabbit pAb used in this study contained high titres of anti-M2e antibodies and indicating that the synthetic $\mathrm{M} 2 \mathrm{eC} 0$ peptide inoculated with Freund adjuvant was immunogenic and could induced high titre of antibodies recognised by both rM2e proteins and synthetic M2e peptides. High antibody titres $(>1 / 32000)$ for rabbit and chicken $\mathrm{M} 2 \mathrm{e}$ pAb were detected in ELISA (result not shown).

M2e protein has been reported as a poor immunogen and induced low or no detectable antibody titres following live infection in humans (Fiers et al. 2004). The antibodies titres from animals or humans infected with IAV were found to be in low titres and of short duration (Feng et al. 2006). However, it has been shown that the M2e synthetic peptide or recombinant M2e protein could induce high titre of antibody in mice and it can bind to the M2e in the surface of MDCK cells infected by PR8 IAV (Wu et al. 2007). When inoculated as a free peptide, M2e induced low $(<100)$ antibody response in mice (Xia et al., 2011), but this immunogenicity was improved by pairing M2e with certain carrier proteins, such as hepatitis B virus core protein, Freund's adjuvant, the Norovirus $\mathrm{P}$ particle and other immunomodulators (Wu et al. 2007; Xia et al. 2011; Li et al. 2011). The number of M2e polyclonal antibodies have been produced and used to study M2e antigenicity (Frace et al. 1999; De Filette et al. 2006).

From direct comparisons of binding to rM2e, two antigenic sites were associated with the positions 10 and 13. Amino acid change at position 10, either P10L or P10S, reduced the antibody binding significantly, indicating that significant proportion of antibodies is directed towards this epitope. Therefore, position 10 is considered as an immunodominant epitope for M2e. At the same position, amino acid change $\mathrm{P} 10 \mathrm{H}$ had less impact on antibody binding. It was evident that by introduction of a single mutation $\mathrm{P} 10 \mathrm{H}$ in $\mathrm{M} 2 \mathrm{eC} 6$ to generate $\mathrm{M} 2 \mathrm{eC} 8$, the binding of antibody to the mutant M2eC8 did not change significantly. The amino acid change at the position 13 , either N13K or N13S, also reduced antibody binding significantly and could therefore be considered as an immunodominant epitope. When comparisons were made between the parent and the mutant M2e, contribution of other amino acid changes to the antigenicity of the M2e became evident. In particular, the change at the position 14 (E14G) was the most common change between M2e of $\mathrm{AIV}$ and caused reduction in antibody binding. In M2e protein with amino acid E14G, additional E16G mutation further reduced antibody binding indicating these two positions might be the part of the same epitope. Another common amino acid change K18R was also reduced the antibody binding, but this was not a consistent finding. In M2e-peptide ELISA using chicken pAb, antigenic differences between proteins were less evident, with amino acid changes P10L and P10S significantly influencing the binding of antibody. Two other amino acid changes that marginally affected the binding of antibody were $\mathrm{E} 14 \mathrm{G}$ and K18R. It is consider that the antigenicity differences between rM2e proteins and M2e peptide are due to the higher affinity of anti-M2e pAb for peptide than for $\mathrm{rM} 2 \mathrm{e}$ protein, resulting in antibody having high titres and less discriminating ability for minor antigens present in a peptide.

Analysis using rabbit pAb indicated that the only amino acid changes that influence the binding were P10L, P10H or P10S. These changes caused the lack of binding equally, which was contrary to the results with chicken $\mathrm{pAb}$. The reason for lesser discriminating value of rabbit $\mathrm{pAb}$ in comparison to chicken $\mathrm{pAb}$ obtained by the same immunisation is speculative. Both sera have been obtained by immunisation with the same peptide and adjuvant, and titres were comparable. While antigenic presentation of immunizing M2e peptide should be the same in both rabbit and chicken, it is possible that chicken, as a natural host for AIV, is more capable to recognise minor antigenic differences and mount an effective immune response. Rabbits have been often used to produce antibody against avian pathogen, including against purified antigens, in which case usually it generate broadly reactive antibody response.

Unlike for chicken and rabbit $\mathrm{pAb}$, the dominant epitope detected by $\mathrm{mAb} 14 \mathrm{C} 2$ was isoleucine at the position 11. The highest reaction of $\mathrm{mAb} 14 \mathrm{C} 2$ was found with the $\mathrm{M} 2 \mathrm{eC} 11$ (figure 1.a), which has isoleucine at position 11 (11I) and homologous sequence to M2e of A/WSN/33 IAV. However, less reaction was found with other $\mathrm{M} 2 \mathrm{e}(\mathrm{M} 2 \mathrm{eC} 3, \mathrm{M} 2 \mathrm{eC} 4$, $\mathrm{M} 2 \mathrm{eC} 10$ and $\mathrm{M} 2 \mathrm{eC} 13$ ), which also had isoleucine at position 11. This indicates that changes at other positions (E14G, G16E and R18K) could also have affected and reduced the binding of $\mathrm{mAb} 14 \mathrm{C} 2$ to M2e. Previously, the M2e protein antigenic sites have been 
determined to be located in the middle part of M2e, which was in the first ten amino acids at the N-terminal end of M2e (Fu et al. 2009). Also, study using mouse mAb 8C6 suggested that the M2e antigenic determinant was located between amino acid residues 8 to 12 (8ETPIR14) (Zou et al. 2005). MAb 8C6 was also reported can not recognise 7-mer M2e peptide containing amino acid substitution either at position 9 (T9A), 12 (R12A) or both positions 9 and 12 (T9A; R12A) (Zou et al. 2008). A panel of M2e human recombinant monoclonal antibodies have also been used for M2e antigenic study and showed that different M2e epitopes, SLLTEVETPIRNEWG, LLTEVETPIRNEWG, LLTEVETPIR, and TPIRNE were recognised by monoclonal antibody L66, N547, Z3G1, and C40G1, respectively (Wang et al. 2008). Hence, different results could have been obtained since every monoclonal antibody could only recognise one often-discrete epitope (Zhang et al. 2006).

In the present study, the M2e specific mouse $\mathrm{mAb}$ 14C2 was used to analyse the M2e antigenicity. WB and ELISA results showed that amino acid substitution at the position 11 (I11T) could destroy the M2e antigenicity. This result was similar to the earlier study (Zebedee \& Lamb 1988) used mAb 14C2 on immunoprecipitation and immunoblot assays, and it showed eight different M2 proteins from heterologous IAV containing different amino acids at the position 11 (I11T) could not be recognised by mAb 14C2. This finding indicates that $\mathrm{mAb} 14 \mathrm{C} 2$ specifically binds to isoleucine at the position 11. The important of isoleucine at position 11 as immunodominant epitope for M2e also reported by study using human mAb 8C6, which specific for the M2e with sequence 5EVETPIRN-14, it showed that mAb 8C6 weakly reacted with GST-5- EVETPTRN-14 (Liu \& Chen 2005). The same study also reported that the residue 10 was the most important amino acid for the M2e antigenicity, that human mAb 8C6 could not bind to GST-EVETLTRN (Liu \& Chen 2005). This finding was supported by previous study, which reported the influenza A virus escape mutant with mutation at position $10(\mathrm{P} 10 \mathrm{~L}$ and $\mathrm{P} 10 \mathrm{H})$, found in mice infected using PR8 influenza A virus and treated with mAb 14C2 (Zharikova et al. 2005).

\section{CONCLUSION}

In summary, the study showed that the M2e antigenic sites are located between residues $10-18$ and amino acid changes at these sites may all affect the antibody binding to M2e protein. It also identified that the capacity for antigenic mapping of the M2e protein was different between antibody raised in chicken and rabbit. Isoleucine position 11 is crucial for antibody binding of $\mathrm{mAb} 14 \mathrm{C} 2$ to M2e. However, the critical amino acid changes for rabbit $\mathrm{pAb}$ and chicken $\mathrm{pAb}$ binding was proline at position 10 . Therefore, these positions 10 and 11 can be considered as the important immunodominant epitopes for M2e.

\section{ACKNOWLEDGEMENTS}

This work was part of the first author's dissertation submitted to University of Melbourne and supported by a grant from the Australian Centre for International Agricultural Research (John Allwright Fellowship, year 2008-2011).

\section{REFERENCES}

Bianchi ATJ, Heinen PP, de Boer-Luijtze EA. 2001. Respiratory and systemic humoral and cellular immune responses of pigs to a heterosubtypic influenza A virus infection. J Gen Virol. 82:2697-2707.

De Filette M, Ramne A, Birkett A, Lycke N, Löwenadler B, Min Jou W, Saelens X, Fiers W. 2006. The universal influenza vaccine M2e-HBc administered intranasally in combination with the adjuvant CTA1-DD provides complete protection. Vaccine. 24:544-551.

Feng J, Zhang M, Mozdzanowska K, Zharikova D, Hoff H, Wunner W, Couch R, Gerhard W. 2006. Influenza A virus infection engenders a poor antibody response against the ectodomain of matrix protein 2 . Virol $\mathrm{J}$. $3: 102$.

Fiers W, De Filette M, Birkett A, Neirynck S, Min Jou W. 2004. A "universal" human influenza A vaccine. Virus Res. 103:173-176.

Frace AM, Klimov AI, Rowe T, Black RA, Katz JM. 1999. Modified M2 proteins produce heterotypic immunity against influenza A virus. Vaccine. 17:2237-2244.

Fu T-M, Freed DC, Horton MS, Fan J, Citron MP, Joyce JG, Garsky VM, Casimiro DR, Zhao Q, Shiver JW, Liang $X$. 2009. Characterizations of four monoclonal antibodies against M2 protein ectodomain of influenza A virus. Virology. 385:218-226.

Furuse Y, Suzuki A, Kamigaki T, Oshitani H. 2009. Evolution of the $\mathrm{M}$ gene of the influenza $\mathrm{A}$ virus in different host species: large-scale sequence analysis. Virol J. 6:67.

Hemmatzadeh F, Sumarningsih S, Tarigan S, Indriani R, Dharmayanti NLPI, Ebrahimie E, Igniatovic J. 2013. Recombinant M2e Protein-Based ELISA: A Novel and Inexpensive Approach for Differentiating Avian Influenza Infected Chickens from Vaccinated Ones.Guan Y, editor. PLoS One. 8:e56801.

Ito T, Gorman OT, Kawaoka Y, Bean WJ, Webster RG. 1991. Evolutionary analysis of the influenza A virus M gene with comparison of the M1 and M2 proteins. J Virol. 65:5491-8.

Kim M-C, Choi J-G, Kwon J-S, Kang H-M, Paek M-R, Jeong 
O-M, Kwon J-H, Lee Y-J. 2010. Field Application of the H9M2e Enzyme-Linked Immunosorbent Assay for Differentiation of H9N2 Avian Influenza VirusInfected Chickens from Vaccinated Chickens. Clin Vaccine Immunol. 17:1977-1984.

Kitikoon P, Strait EL, Thacker EL. 2008. The antibody responses to swine influenza virus (SIV) recombinant matrix 1 (rM1), matrix 2 (M2), and hemagglutinin (HA) proteins in pigs with different SIV exposure. Vet Microbiol. 126:51-62.

Lam TT-Y, Hon C-C, Pybus OG, Kosakovsky Pond SL, Wong RT-Y, Yip C-W, Zeng F, Leung FC-C. 2008 Evolutionary and Transmission Dynamics of Reassortant H5N1 Influenza Virus in Indonesia.Holmes EC, editor. PLoS Pathog. 4:e1000130.

Lamb RA, Zebedee SL, Richardson CD. 1985. Influenza virus M2 protein is an integral membrane protein expressed on the infected-cell surface. Cell. 40:627633.

Lambrecht B, Steensels M, Van Borm S, Meulemans G, van den Berg T. 2007. Development of an M2e-Specific Enzyme-Linked Immunosorbent Assay for Differentiating Infected from Vaccinated Animals. Avian Dis. 51:221-226.

Li R, Lim A, Ow STL, Phoon MC, Locht C, Chow VT, Alonso S. 2011. Development of live attenuated Bordetella pertussis strains expressing the universal influenza vaccine candidate M2e. Vaccine. 29:55025511.

Liu W, Chen Y-H. 2005. High epitope density in a single protein molecule significantly enhances antigenicity as well as immunogenicity: a novel strategy for modern vaccine development and a preliminary investigation about B?cell discrimination of monomeric proteins. Eur J Immunol. 35:505-514.

Marché S, Lambrecht B, van den Berg T. 2010. Evaluation of Different Serologic Markers for the Early Detection of Avian Influenza Infection in Chickens. Avian Dis. 54:690-698.

Mozdzanowska K, Feng J, Eid M, Kragol G, Cudic M, Otvos L, Gerhard W. 2003. Induction of influenza type A virus-specific resistance by immunization of mice with a synthetic multiple antigenic peptide vaccine that contains ectodomains of matrix protein 2. Vaccine. 21:2616-2626

Schotsaert M, De Filette M, Fiers W, Saelens X. 2009. Universal M2 ectodomain-based influenza A vaccines: preclinical and clinical developments. Expert Rev Vaccines. 8:499-508.
Tarigan S, Indriani R, Durr PA, Ignjatovic J. 2015. Characterization of the M2e antibody response following highly pathogenic $\mathrm{H} 5 \mathrm{~N} 1$ avian influenza virus infection and reliability of M2e ELISA for identifying infected among vaccinated chickens. Avian Pathol. 44:259-268.

Wang R, Song A, Levin J, Dennis D, Zhang N, Yoshida H, Koriazova L, Madura L, Shapiro L, Matsumoto A. 2008. Therapeutic potential of a fully human monoclonal antibody against influenza A virus M2 protein. Antiviral Res. 80:168-177.

Wang Y, Zhou L, Shi H, Xu H, Yao H, Xi XG, Toyoda T, Wang X, Wang T. 2009. Monoclonal antibody recognizing SLLTEVET epitope of M2 protein potently inhibited the replication of influenza $A$ viruses in MDCK cells. Biochem Biophys Res Commun. 385:118-122.

Wibowo MH, Tarigan S, Sumarningsih, Artanto S, Indriani R, Anggoro D, Putra CP, Idris S, Untari T, Asmara W, et al. 2017. Use of M2e ELISAs for longitudinal surveillance of commercial poultry in Indonesia vaccinated against highly pathogenic avian influenza. J Virol Methods. 249:181-188.

Wu F, Huang J-H, Yuan X-Y, Huang W-S, Chen Y-H. 2007. Characterization of immunity induced by M2e of influenza virus. Vaccine. 25:8868-8873.

Xia M, Tan M, Wei C, Zhong W, Wang L, McNeal M, Jiang X. 2011. A candidate dual vaccine against influenza and noroviruses. Vaccine. 29:7670-7677.

Zebedee SL, Lamb RA. 1988. Influenza A virus M2 protein: monoclonal antibody restriction of virus growth and detection of M2 in virions. J Virol. 62:2762-72.

Zhang M, Zharikova D, Mozdzanowska K, Otvos L, Gerhard W. 2006. Fine specificity and sequence of antibodies directed against the ectodomain of matrix protein 2 of influenza A virus 次. Mol Immunol. 43:2195-2206.

Zharikova D, Mozdzanowska K, Feng J, Zhang M, Gerhard W. 2005. Influenza Type A Virus Escape Mutants Emerge In Vivo in the Presence of Antibodies to the Ectodomain of Matrix Protein 2. J Virol. 79:66446654.

Zou P, Liu W, Chen Y-H. 2005. The epitope recognized by a monoclonal antibody in influenza A virus M2 protein is immunogenic and confers immune protection. Int Immunopharmacol. 5:631-635.

Zou P, Liu W, Wu F, Chen Y-H. 2008. Fine-epitope mapping of an antibody that binds the ectodomain of influenza matrix protein 2. FEMS Immunol Med Microbiol. 53:79-84. 